\title{
PRICE LEVEL STABILIZATION: HAYEK CONTRA MAINSTREAM ECONOMICS
}

\section{Pavel Potužák}

\begin{abstract}
The doctrine of beneficial effects of price level stabilization is an integral part of modern mainstream economics. In the 1920s and 1930s, Friedrich August von Hayek questioned this monetary policy regime, and stressed injection effects of the newly created money aimed at price level stabilization in the economy with expanding natural output. This paper compares the Hayekian theory with mainstream economics. A simple graphical apparatus is used to clarify major differences between the two theories. Standard textbook models are applied to show why the Hayekian approach favours secular deflation over price level stabilization which may lead to the boom-bust cycle. The next section presents New Keynesian arguments in favour of stable prices or even low inflation, and it shows why the Hayek recommendations may result in quasi-recession. The "Wicksellian" equation, which relates inflation gap to the real interest rate gap, is derived to reconcile the Hayek approach with the mainstream perspective. Finally, it is demonstrated that New Keynesian price rigidities might be of much lower importance when the decline in prices is caused by technological progress. A gradually falling price level is then identified as a natural response of the price system in the expanding economy.
\end{abstract}

Keywords: price level stabilization, natural rate of interest, business cycle, Hayek

JEL Classification: E42, B25, B53

\section{Introduction}

Since the time of Wicksell (1936), when the doctrine of price level stabilization was put on rigorous grounds, it has become one of the most popular among competing monetary theories. The modern inflation targeting regime might be considered as its direct successor. The most consistent attack on this theory was made by Hayek (1935). The major idea of this Austrian economist was that the natural response of the price system in the economy with expanding potential output is a fall in the general level of prices. Injections of money aimed at stabilizing the price level may lead to the business cycle and should be therefore avoided.

The major objective of this paper is to examine the Hayekian approach and to compare this theory with the modern mainstream paradigm of the superiority of pricelevel stabilization. The analysis is focussed on different views about the optimal behaviour of the price level when the aggregate supply is expanding at the natural rate. Responses of the central bank to shocks in aggregate demand are not studied in this article, as views

* Pavel Potužák, Faculty of Economics, University of Economics in Prague, Prague, Czech Republic (pavel.potuzak@vse.cz).

The author would like to thank anonymous referees for helpful comments, and acknowledge the support of grant IG506016, 26/2016 provided by the University of Economics, Prague. 
of the two theories are much closer as far as shifts in $A D$ are concerned. Nonetheless, from the Austrian perspective the seeds of future (demand-driven) recessions ought to be found in previous periods of seemingly sound economic growth. Thus, the approach employed in this paper can be considered as more general because it deals with the prevention of economic depression rather than fighting it once it hits the economy.

Since the Austrian theory has never been developed into a rigorous mathematical model, the article will analyse the Hayek ideas in a diagrammatic model of mainstream economics, which will, however, extend the graphical approach of modern Austrian authors.

The paper is organized as follows. Section 2 presents a growing economy and a structure of relative prices that is consistent with this path in the Hayek theory. Section 3 highlights that a gap between the natural and the actual rate of interest may emerge even in the economy with stable prices, which questions the core of the Wicksellian theory. Sections 4 and 5 compare the Austrian analysis with mainstream economics in a simple IS-LM-Y* model and in the AD/AS framework. These parts also show how the views of Hayek and Wicksell on price level stabilization can be reconciled. The view of the latter author is then extended by constructing the "Wicksell equation", which is derived from a simple New Keynesian model and which indicates superiority of the Hayek perspective. Section 6 demonstrates that the New Keynesian price-rigidity arguments should be reconsidered when pressures on the decline in the price level are caused by technological progress. The last part summarizes major findings of the paper.

\section{Relative Prices in a Growing Economy}

This section describes the major argument of Hayek (1935) against price level stabilization in a growing economy. Hayek was not the only author in the pre-Keynesian period who argued in favour of price deflation when the total volume of goods is growing. Similar arguments can be found in Bradford (1929) and Allan Fisher (1935). The overview of opinions on price level stability in the history of economic thought is provided by Selgin (1995).

Robbins (1934) and Rothbard (2000) applied the Hayek theory to explain the Great Depression, the causes of which they detected in monetary policy of the 1920s that aimed at price level stabilization.

The best known modern Austrian protagonist and follower of these ideas is Selgin (1997) who presented the "productivity norm" framework for monetary policy, which resembles Hayek recommendations to stabilize $M V$ (total nominal spending in the economy) rather than the price level.

White (1999) indicated inconsistency in the Hayek (1976) later works, in which Hayek permitted stabilization of an index of prices of commodities. Komrska and Hudík (2016) explained that this alleged inconsistency is illusive.

In modern non-Austrian literature, Atkeson and Kehoe (2004), Bordo et al. (2004), Bordo and Filardo (2004), and Borio et al. (2015) showed that deflation episodes were not necessarily linked to economic recessions, and many historical periods were characterized by "good" deflation during rapid economic growth. 
Hayek $(1933,1935)$ stressed that the majority of real world economies are growing in the long run. Consider an economy in which the natural output is expanding due to technological progress that is, however, not uniform across the economy. This assumption is consistent with the fact that productivity in the ICT sector is increasing at a more rapid pace than that of hairdressers and other types of personal services.

Suppose that the general Walrasian equilibrium was established in a system of $n$ markets. Three representative (perfectly competitive) markets are displayed in Figure 1. Rapid technological progress is underway in market $A$, a modest one in market $B$, and market $C$ is characterized by stable technologies. Advances in technologies in market $A$ are reflected in the rightward shift of the supply curve, which lowers price $P_{A}$ in this market. The decrease of price in market $B$ is not so remarkable, and finally, there is no change in the supply curve and hence the market price in market $C$.

Obviously, a change in the individual price depends on more factors. It is an open question of how much the given rate of technological progress is transmitted to the reduction of costs in the particular industry. Secondly, a drop in the price in the given market is affected by the elasticity of demand. Substitution and complementary connections play also an important role among markets, so a change in the price in one market may shift the demand in the other market in one direction or another. However, suppose that in the given period, the Walrasian equilibrium is consistent with the system of prices presented in Figure 1.

\section{Figure 1 | Non-Uniform Economic Growth and the Structure of Relative Prices}

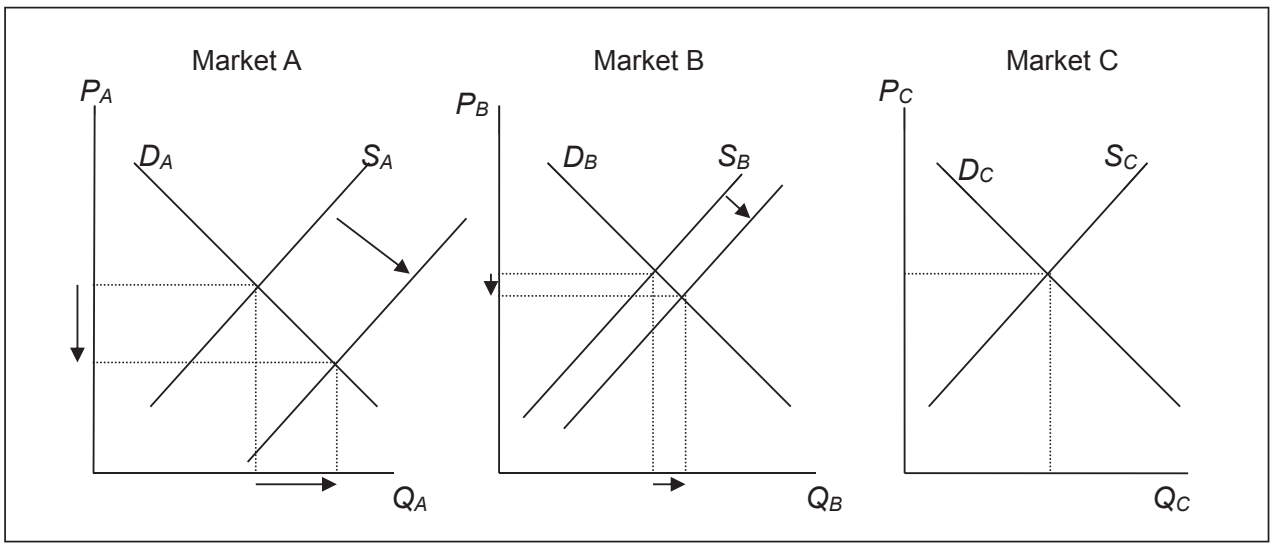

Source: Own construction

Technological progress induces a change in the structure of relative prices: $P_{A} / P_{C}, P_{A} / P_{B}$, and $P_{B} / P_{C}$ decrease. According to Hayek (1935), only this new structure is consistent with the general equilibrium. As it takes time to establish such equilibrium and continuing technological progress may push it to a different position, markets tend to move to equilibrium rather than ever achieving one. However, if the price system operates reasonably well, markets should eventually achieve a position that is close to a point envisioned by 
the general equilibrium theory as a state of rest. Unless the system is hit by an external shock, it should stay there.

Technological progress may cause not only an adjustment of relative prices but also a change in the structure of aggregate output and of incomes for factors of production. Most importantly, Figure 1 shows that the attainment of the new general equilibrium is consistent with a decline in the price level.

Another question is the evolution of wages. As the growth in productivity is most rapid in market $A$, the labour force might be attracted to this sector. However, a decline in the price of good $A$ may operate in the opposite direction because it lowers the value of the marginal product of labour. The difference in nominal wages among markets might be also partly eliminated by a movement of the labour force, assuming reasonable homogeneity of labour.

Even though changes in relative prices can be significant due to non-uniform technological progress, mobility of the labour force tends to equalize nominal wages among industries. Since technological progress decreases prices, the real wages, i.e. the number of consumption goods which can be purchased by the given nominal wage, grow. As a result, even for constant nominal wages, the growth in real wages is achieved by a decline in the general price level (Bradford, 1929).

Figure 2 displays the equilibrium at the macroeconomic level in a simple AD/AS model. It presents technology driven economic growth that gradually raises potential output $Y^{*}$. Assuming a fixed money supply and velocity of circulation, the aggregate demand schedule $A D$ stays constant as well as the system of market demand curves in Figure 1. According to the Hayek theory, the general equilibrium is achieved at point $E_{2}$, at which the system of relative prices from Figure 1 is preserved, and the price level falls.

Figure 2 | Economic Growth and a Decrease in the General Price

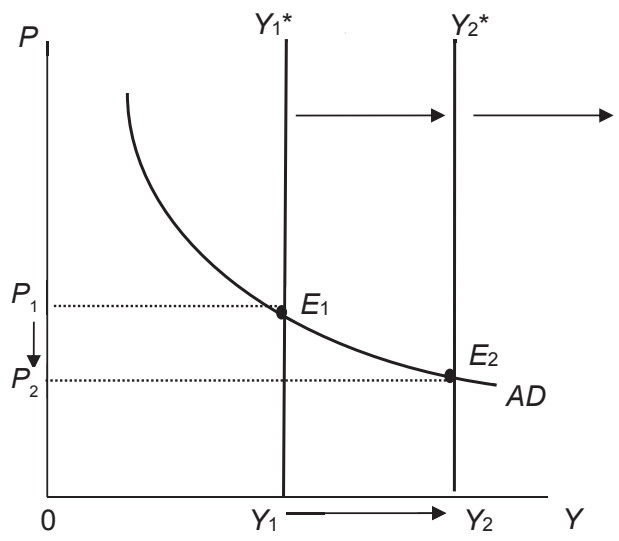

Source: Own construction 
Since the time of Wicksell (1936), it has been believed that the state closest to the ideal of general equilibrium is represented by the stability of the price level. Either a decreasing or an increasing level of prices signals that the general equilibrium was not achieved (Cassel, 1928). Hayek (1935) opposed this view and suggested that linking stability of the price level with the natural state of the economy might be fallacious. In a growing economy, if the price level is to be stabilized, a general increase in the nominal demand is required. The increase in nominal aggregate expenditures may be delivered by the growth in the total money supply. A higher money supply raises nominal demand in markets and consequently may move the price level to the previous level.

It is an indisputable fact that the economic growth (greater $Y^{*}$ ) raises not only supply but also demand in many individual markets. However, the aggregate demand $A D$ (implicitly defined in its simplest form as $M V=P Y$, explicitly as $Y=M V / P$ ) cannot be shifted by a pure increase in $Y^{*}$, since unless people dissolve part of their money balances (increase in $V$ ), ${ }^{1}$ there is not enough money (constant $M$ ) to do this job. In other words, with constant money and velocity, total nominal expenditure in the economy remains constant $\left(P_{1} Y_{1}=P_{2} Y_{2}\right)$, and the growth in the total quantity of goods (i.e. greater real aggregate output $Y$ ) should be reflected in a lower price level $P$. When the potential output $Y^{*}$ is growing, the Wicksellian maxim of the constant price level would require either an increase in the total money supply $M$ or an increase in the velocity of circulation $V$ (a decrease in the demand for money due to lower Cambridge $k$ ).

As far as the impact of the monetary expansion on the real economy is concerned, Hayek (1935) followed ideas of Mises (1976): the influx of money into the economy never enters all markets at the same time and to the same extent. As a result, market prices are never affected simultaneously. Markets and prices influenced first are those that the money inflow enters first. In these markets the nominal demand rises, whereas other markets may not be affected in the first round.

Figure 3 presents this Misesian idea. Market $A$ absorbs the majority of new money, which is reflected in the shift of the demand curve $D_{A}$. The minority of the newly created money enters market $C$, whereas market $B$ is not, in the first round, affected.

1 There is no reason to believe that economic growth brings about a secular increase in $V$ (i.e. a lower $k$ in the Cambridge demand for money equation $\left.M_{d}=k P Y\right)$ as much as to believe that it is accompanied by the opposite tendency. Furthermore, one must critically distinguish between the movement along the $A D$ curve (i.e. a fall in $P$ causes an increase in $Y$ ) and the shift of the entire curve (due to greater $M$ or $V$ the $A D$ curve moves outwards). Greater real wages brought about by the increasing potential output $Y^{*}$ may shift (or may not, since nominal wages may be constant, as was discussed above) the individual demand curves in Figure 1. However, because the pure increase in $Y^{*}$, not accompanied by greater $M$ or $V$, cannot shift the $A D$ curve, and because (labour-augmenting) technological progress is the driving force of both increasing real wages and the increasing $Y^{*}$ (both at the rate $g$ ), rising real wages cannot shift the $A D$ either. And finally, there is no a priori reason to believe that the increasing real wages (total real income $Y$ in general in the Cambridge $M_{d}$ equation) have any impact on the velocity of circulation $V$ (on Cambridge $k$ ). A rigorous mathematical analysis is in Appendix 1. 


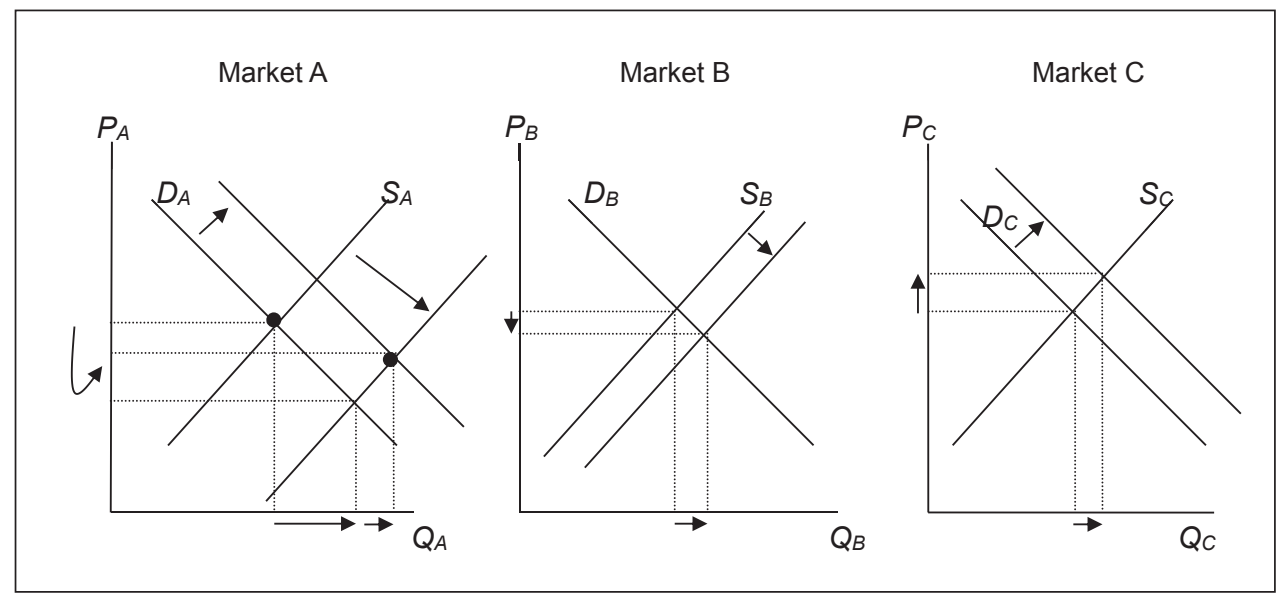

Source: Own construction

As can be seen, the expansion of the money supply may stabilize the average level of prices, but the system of relative prices is disturbed: $P_{A} / P_{C}$ and $P_{A} / P_{B}$ are higher than in the "natural economy", $P_{B} / P_{C}$ is lower. Furthermore, none of the individual prices move back. $P_{A}$ and $P_{B}$ are still lower, whereas $P_{C}$ is above the initial level. Along with the change in relative prices, the structure of the aggregate output is modified as well. More factors of production may be attracted to markets $A$ and $C$ due to monetary expansion. It might be suggested that the aggregate output rises too. However, if the economy operates at the potential level $Y_{2}^{*}$ and if there are no frictions, the output in markets $A$ and $C$ may be increased only at the expense of other markets. It is generally believed that in the long run the economy cannot produce more only due to a larger supply of money, so the system of curves in Figure 3 is not complete. Money expansion should also raise nominal wages (i.e. costs of firms), which will shift the supply curves backwards. These shifts are not drawn in Figure 3 for the sake of clarity. The eventual structures of relative prices and output, and the deviation from the "natural structure", are hard to determine.

Implications of the Hayek theory are straightforward. Technological progress and the increase in potential output are consistent with one specific system of "natural relative prices" that does not disturb the "natural equilibrium". This general equilibrium requires a decline in the price level. An attempt to stabilize the price level via the expansion of the money supply may disturb this "natural equilibrium" owing to the impact on the system of relative prices and consequently on the structure of output. According to Hayek $(1933,1935)$ a stable price level does not imply that money is neutral with respect to the real economy. In the expanding economy, the neutrality of money is preserved only when prices decline. 


\section{Interest Rate Gap in a Growing Economy}

The previous section was concerned with the change in the intra-temporal structure of relative prices that was induced by positive economic growth and with the distortion of this structure when the monetary expansion was carried out in the effort to stabilize the general price level. However, since both the economic growth and the business cycle are dynamic phenomena, the intertemporal analysis should be the centre of our investigations.

Neoclassical economic growth models suggest that if the rate of (labour augmenting) technological progress, the subjective discount rate, and the intertemporal elasticity of substitution in consumption are constant, the natural rate of interest on the balanced growth path should be constant as well. Technological progress is thus not only the driving force of the growth in potential output but it is also one of the determinants of the natural rate of interest.

The picture of the economy presented in the previous section is consistent with such a state. The real output is growing at some definite rate, and the natural rate of interest is constant. According to Hayek, the price level should be declining; otherwise the general equilibrium will be disturbed. At this point, Hayek (1984) stressed the adjective "intertemporal" in the general equilibrium analysis. In the expanding economy, the "natural system" of intertemporal prices is preserved only if the general price level is decreasing. The key intertemporal price that coordinates intertemporal allocation of resources is the rate of interest. Thus, according to Hayek (1935), in a growing economy the actual interest rate will be equal to the natural level only if the price level is allowed to decline.

However, this conclusion is at variance with the Wicksellian theory. Wicksell (1936) concluded that a changing price level indicates that the actual market rate of interest is not at the natural level. If the price level is increasing, the banking system lowered the market rate of interest below the natural level, whereas when prices are falling, the actual market rate was raised above the natural level. Only if the interest rate in the banking system was equal to the natural interest rate, the price level would be stable (Cassel, 1928).

Hayek (1935) argued that the Wicksellian analysis is valid only in a stationary economy. In a growing economy, the equality of the two rates is consistent with a decreasing price level. Stabilization of prices requires an increase in the total money supply. This monetary expansion must depress the market rate of interest below the natural level. Hayek therefore concluded that in the expanding economy, the interest rate is at the natural level and prices are falling, or the price level is constant, but the market rate of interest must be lowered below the natural level. ${ }^{2}$

Furthermore, if the interest rate is depressed below the natural level, the Austrian theory predicts that an unsustainable economic expansion will be triggered. The reason is that an artificial lowering of the interest rate leads to an undue lengthening of the capital structure. Longer methods of production attract factors of production from sectors that provide consumption goods in shorter periods. According to this theory, the interest rate

$2 \quad$ Haberler (1946, p. 35) pointed out that this conclusion was first made by David Davidson. 
will eventually return to the natural level, but longer processes cannot be finished due to a higher interest rate. This reversion process coins the end of the economic boom and a path to recession. ${ }^{3}$

Since the attempt to stabilize the general price level in a growing economy may cause economic fluctuations, the theories of economic growth and business cycle are interwoven in the Hayekian framework. Expansion of the money supply increases the supply of loanable funds. The resulting lower interest rate stimulates investment activity. In the initial phase, the economy may grow at a higher rate than can be attributed to technological progress. One component of economic growth is sound as it reflects technological improvements; the other part is artificial because it is maintained by the monetary expansion (Cochran et al., 2003). In this situation, the unsustainable boom can be perfectly consistent with a stable price level.

The period of seeming prosperity can be prolonged by an increasing rate of money expansion, but price stability then turns to an explicit positive inflation. The central bank with the price stability mandate may stop this process, and the economic boom turns to bust. It is an open question whether the total level of aggregate output will fall or whether it will just be growing at a lower rate. Nonetheless, according to the Austrian theory the economy must undergo this business-cycle pattern.

Since capital was lengthened artificially in the expansion phase of the business cycle, some capital structures may be lost in the downswing phase causing a fall in the potential output. The eventual levels of the potential output and the natural rate of interest are therefore hard to determine. As a result, stability of the price level does not imply that money is neutral with respect to the real economy (Hayek, 1935).

It should be stressed that the more rapid is the technological progress the stronger pressures on the decline in the price level are provoked, assuming constant money and velocity. Stabilization of the price level then requires a substantial increase in the money supply, which may trigger economic boom and consequent bust. Thus, the higher the growth in natural output (if accompanied by monetary accommodation), the higher the likelihood that the economy will experience the Austrian-style business cycle. Hayek (1933) therefore concluded that business cycles should prevail in (secularly) growing, rather than stationary, economies.

\section{Austrian Theory in the Keynesian Framework}

This section presents Austrian theory in a simple textbook Keynesian model that pins down key differences between this theory and mainstream economics. Garrison (2001) presented secular growth in the Austrian model. In Figure 4, investment and saving grow at the same rate, and the natural rate of interest is constant. Such an idea is indistinguishable from the balanced growth path (BGP) in neoclassical growth models.

In Figure 4, the expanding Hayek triangle, representing a structure of capital in the economy, maintains its shape because the natural rate of interest is constant.

3 Recent empirical tests of the Austrian business cycle theory can be found in Komrska (2015), and Mandel and Tomšík (2015). 
In neoclassical models, the BGP is consistent with a stable capital-output ratio. In the Hayek triangle, this means that the height of the vertical line measuring consumption goods, is expanding at the same rate as the area of the triangle representing the capital stock in the economy. This conclusion implies that forces of technological progress, which may create shortening tendencies in the production process, are offset by lengthening tendencies that arise due to the accumulation of capital.

Figure 4 | Secular Growth in the Austrian Model

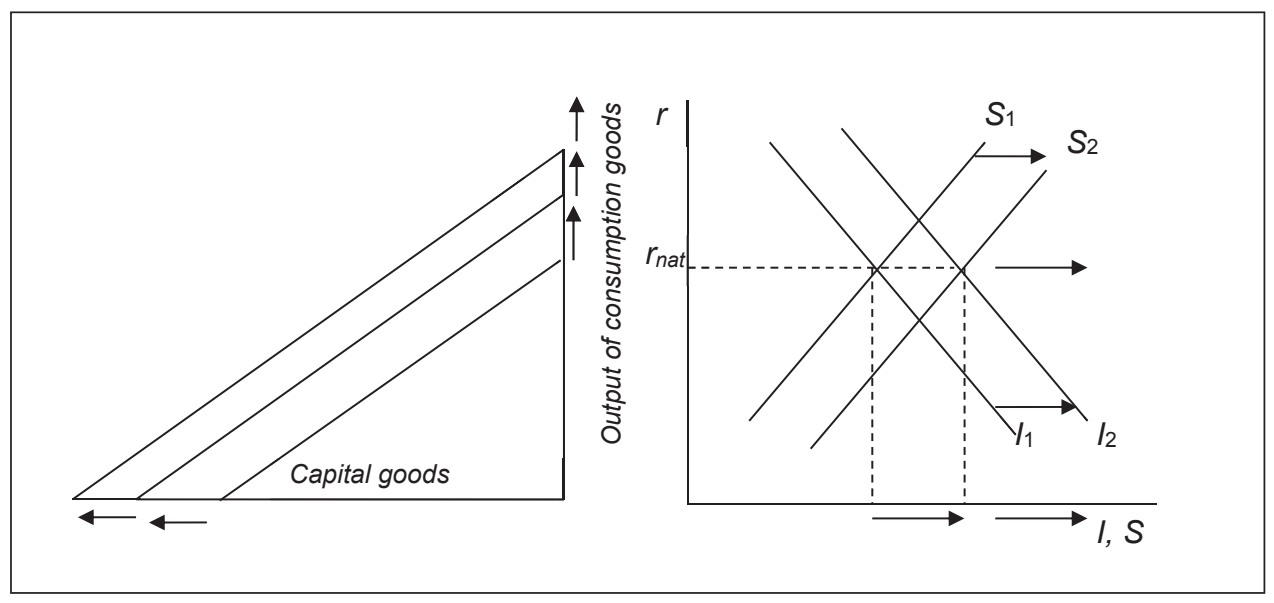

Source: Modified picture from Garrison (2001, p. 54)

In the Garrison model, the (potential) output is growing, and the natural rate of interest is constant. This combination can be sketched in a space that differs from the loanable funds market. Expanding potential output and constant natural interest rate are plotted in the output-interest rate space in panel (a) of Figure 5.

It might be useful not to lose information from the loanable funds market. Investment and saving equilibrium in space $(Y, r)$ is represented by the $I S$ curve: greater incomes generate higher saving and hence a lower interest rate (Mankiw, 2009). Thus, the second curve that is missing in panel (a) is the $I S$ curve, depicted in panel (b).

Figure 5 not only shows the BGP in a simple IS-Y* model, but it also depicts the New Keynesian definition of the natural rate of interest (Williams, 2003, p. 1). In this strand of literature, Amato $(2005$, p. 732) interpreted the original position of Wicksell $(1936,1977)$ as follows: the natural interest equilibrates saving and investment, it is consistent with the marginal product of capital, or with price stability.

The genuine New Keynesian vision of the natural interest emphasizes a different aspect: it is the interest rate when the economy operates at the natural, i.e. flexible price, level (Woodford, 2003, p. 9). Woodford (ibid., p. 53) also stressed that the natural interest depends on the marginal productivity of capital and on the time preference, which is a Fisherian 
approach. Moreover, Woodford linked this definition to what he called the flexible-price IS curve. Apart from the determinants of the natural interest rate mentioned by Woodford, Amato $(2005$, p. 3 ) added the willingness to substitute consumption over time. Laubach and Williams (2003, p. 64) revealed that the natural rate of interest is affected by the growth rate of potential output. Yet they also highlighted that the natural interest is consistent with the natural output and stable inflation (ibid., p. 63). A similar position is held by Orphanides and Williams (2002, p. 64).

Figure 5 | Balanced Growth Path and the Natural Interest Rate in the (New) Keynesian Model

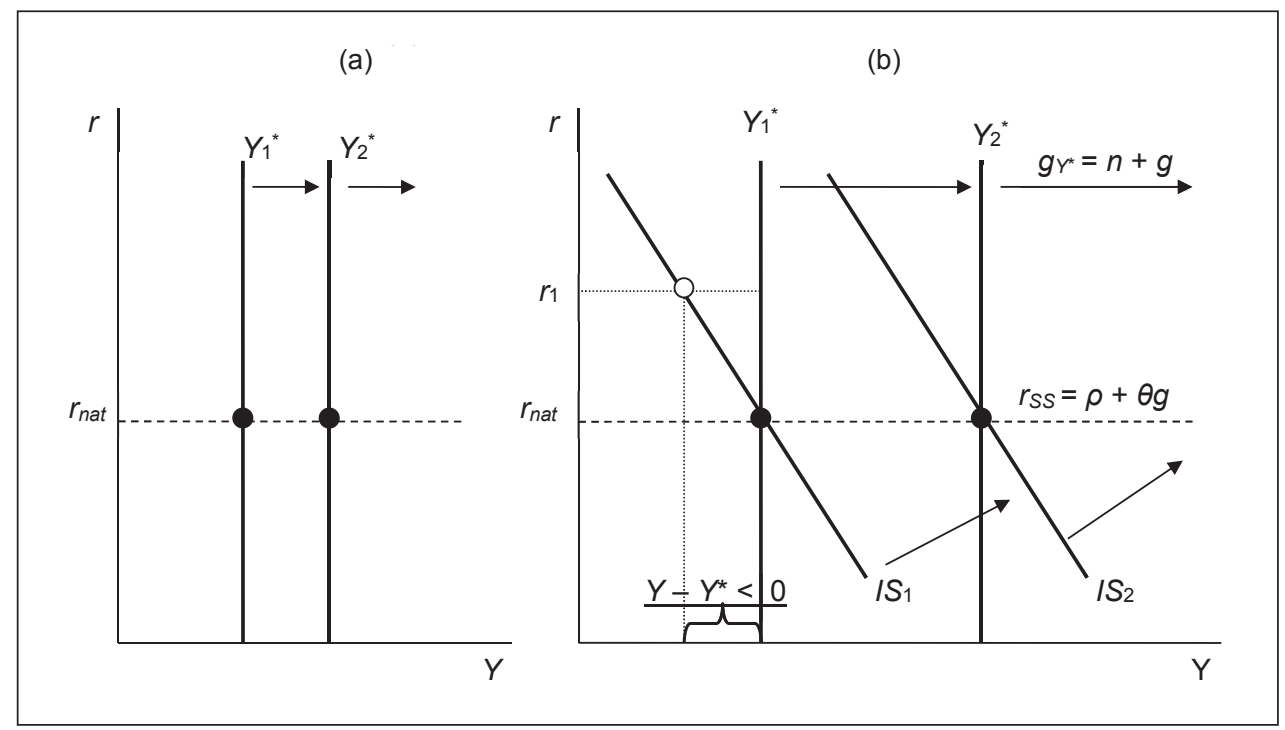

Source: Own construction

The natural rate of interest in the New Keynesian vision lies at the intersection of the natural output with the New Keynesian IS-curve, which is derived as the Euler equation in the intertemporal optimization problem (Woodford, 2003). Panel (b) also shows that if the actual rate of interest is higher than the natural rate $\left(r_{1}>r_{n a t}\right)$, the difference between the actual output and the natural output is negative, ${ }^{4}$ creating a negative output gap, whereas the opposite statement holds if the actual interest rate is below the natural level.

In Figure 5, the economy is assumed to be on the BGP. The growth rate of potential output is then equal to the sum of the rate of technological progress $g$ and the population/ labour force growth $n\left(g_{Y^{*}}=g+n\right)$. The natural interest rate is at the steady state/BGP level $r_{s s}$. In the Ramsey-Cass-Koopmans model, this level is equal to $r_{s s}=r^{*}=\rho+\theta g$ (Romer, 2006), where $\rho$ is the subjective discount rate reflecting pure time preference

$4 \quad$ For simplicity, "natural output" and "potential output" are used interchangeably. 
(Potužák, 2016a,b), 1/ $\theta$ is the intertemporal elasticity of substitution in consumption derived from the CRRA (CIES) instantaneous utility function $u=C^{1-\theta} /(1-\theta)$, and $g$ is the growth rate of exogenous labour-augmenting technological progress. The natural rate of interest on the BGP thus depends on determinants discussed in the New Keynesian literature.

The $I S$ curve in panel (b) expands at the same rate as the potential output $Y^{*}$ since positive technological progress (and the population/labour-force growth) raises marginal product of capital and consequently the investment demand. In the core New Keynesian model this shift is caused by the increasing expected future potential output (Woodford, 2003; Galí, 2008), induced in this case by the same source $(g+n)$. It should be stressed that the steady-state/BGP interest rate is a special case of the natural level. The natural interest rate may differ from this level if the economy is converging to the steady-state/BGP.

The Hayek theory suggests that in a growing economy the price level should be decreasing. An attempt to stabilize the price level by an expansion of the money supply triggers the boom-bust cycle. To demonstrate this idea in the framework discussed above, one more building block - the money market - must be added into the IS-Y* model.

This extension is straightforward because $(Y, r)$ space perfectly fits the definition of the $L M$ curve. ${ }^{5}$ The $L M$ curve requires that the real demand for money is negatively related to the interest rate and positively related to real income. It can be derived from microeconomic foundations when money is included in the utility function (Woodford, 2003, p. 104), or if it facilitates transactions (McCallum, 2000, p. 872). In these models, a higher real income (or consumption) requires larger real money balances, so the interest rate must increase to equilibrate the money market. Yet, this construction holds for a fixed price level. If the price level is flexible, as has been assumed so far, a higher real demand for money is reflected in lower prices. Accepting this point of view, the IS- $Y^{*}$ model is extended into a flexible price IS-LM-Y* model (Woodford, 2003, p. 109).

This model is presented in Figure 6. All curves are drawn linear for simplicity. The mathematical background of the presented models is in Appendix 1. An upward sloping $L M$ curve shows combinations of output and interest rate that are consistent with the equilibrium on the money market, assuming a fixed price level. This curve is rather a shadow curve in the model because the Austrian framework assumes flexible prices.

Hayek (1935) concluded that increasing potential output should be accompanied by a decline in the price level, as was displayed in Figure 2. Figure 6 represents the same theory in the flexible price IS-LM-Y* model. The natural output is growing at a positive rate, and the natural rate of interest is constant. The secular decline in the price level from $P_{1}$ to $P_{2}$ shifts the $L M$ curve (panel a). Rising real incomes are reflected in higher real demand for money $L$, which is satisfied by a decreasing price level (panel b), even if the nominal money supply is constant $\left(M_{s}^{\text {const }}\right)$. As can be seen, the actual rate of interest is at the natural level;

5 The money market equilibrium is to be derived for the nominal interest rate. Assuming zero expected inflation, nominal interest and real interest coincide. A difference between the two rates, which arises due to positive expected inflation or deflation, would not affect major findings presented in this paper. 
yet the price level is falling. The model closely follows Hayek ideas as only this behaviour of the interest rate and prices is consistent with the intertemporal general equilibrium. ${ }^{6}$

Figure 6 | Balanced Growth Path and a Secular Decrease in the Price Level

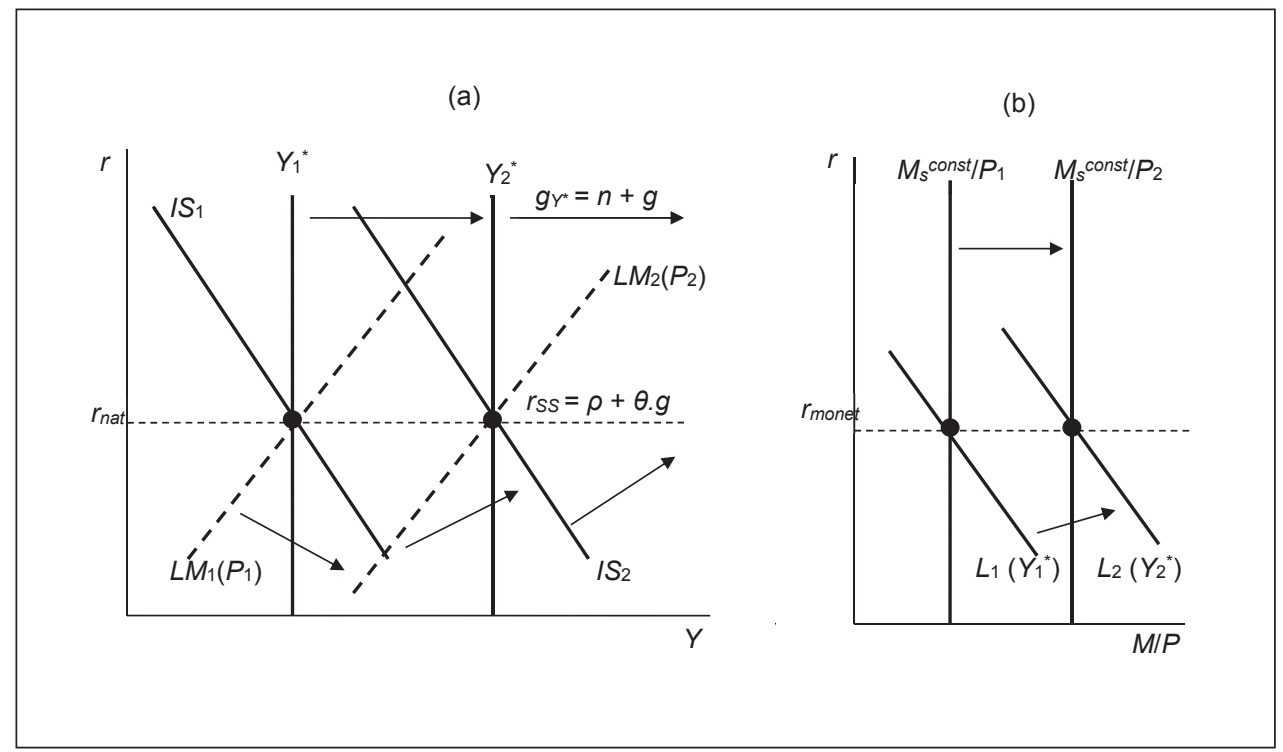

Source: Own construction

If the monetary authority is determined to keep the price level constant, it must inject money into the economy. This may trigger the boom-bust cycle. Figure 7 plots the Hayekian analysis in the IS-LM-Y* model. Monetary expansion lowers the interest rate below the natural level $\left(r_{2}<r_{n a t}\right)$. If the short-run aggregate supply is non-vertical, the actual output rises above the potential level $\left(Y_{2}>Y_{2}^{*}\right)$. Panel (b) represents this theory in the AD/ AS model (Selgin, 1997, p. 38; Beckworth, 2008, p. 373). The eventual shift of the $L M$ curve $\left(L M_{4}\right)$ in panel (a) reflects not only the initial increase in the money supply but also the response of the price level from $P_{2}$ back to $P_{1}$.

At point $D$, the economy is not in the long-run equilibrium. The natural rate hypothesis predicts that the economy should end up at point $E$ at which output is back at the potential level. The interest rate returns to the natural level as well, but the price level is higher than in the initial state. The movement to this point would be represented by a shift of the AS curve in panel (b) backwards, and the $L M$ curve in panel (a) back to position $L M_{2}$. These shifts are not presented in the figure to keep clarity of the exposition. As can be seen, the action of the central bank was not successful in the long run, because it overshot the targeted price level.

$6 \quad$ The expected deflation, which arises in this situation, and its impact on the real demand for money may temporarily speed up deflation beyond the rate $n+g$. However, the very long-run BGP deflation $n+g$ is not affected. 


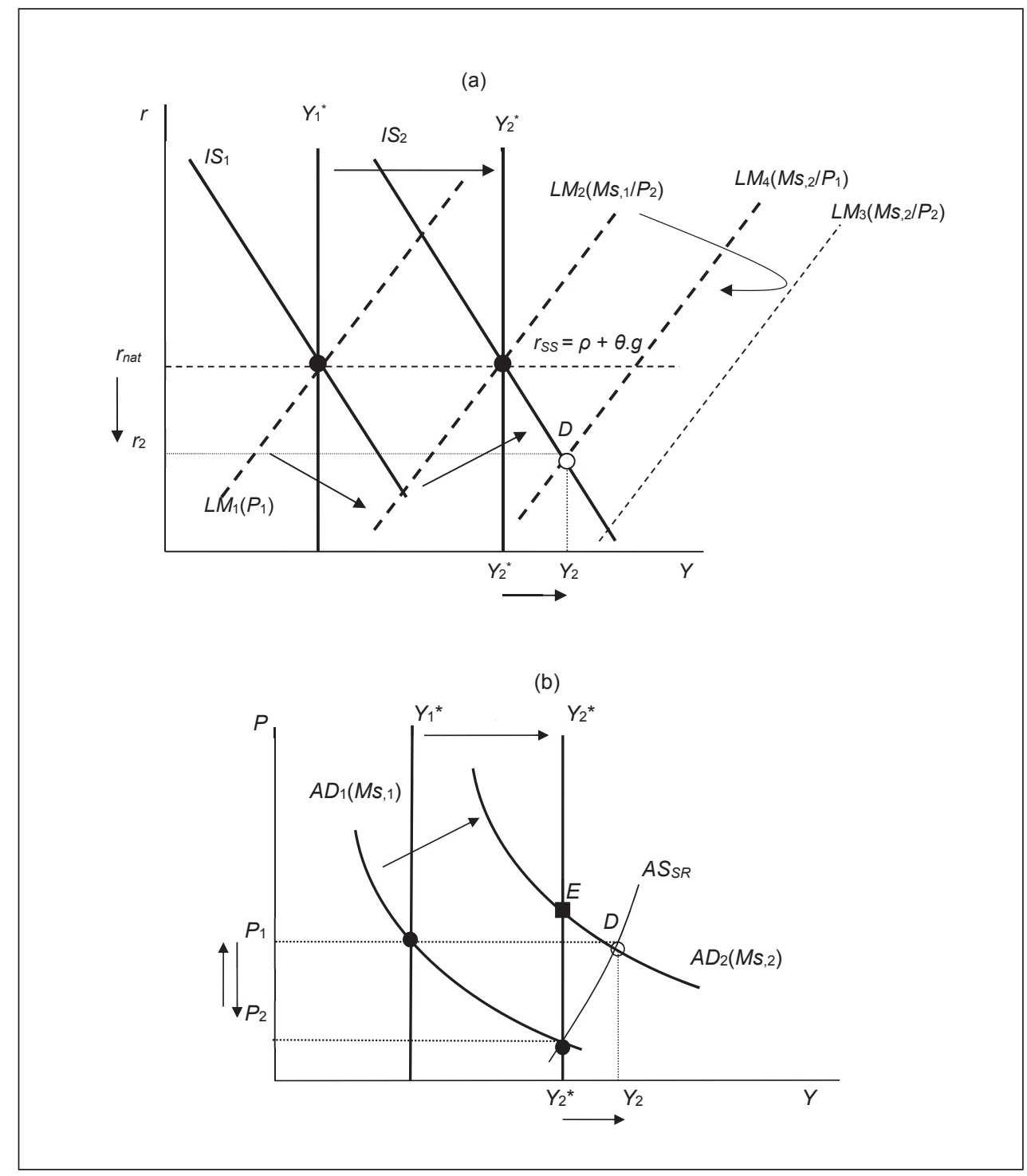

Source: Own construction

However, in the Austrian theory the dynamics of the economy especially in the recessionary state is not as simple as suggested by the natural rate hypothesis. As was discussed in Section 3, the Austrian recession is characterised by losses of capital structures due to misallocation of resources in the boom phase of the business cycle. This may negatively affect the potential output. 
Furthermore, if the increase in the money supply took the form of the expansion of deposits (and hence credit), recessionary forces leading to bankruptcies of firms may reduce the demand for credit and then contract the amount of deposits. This would be reflected by a leftward shift of the $L M$ curve. $^{7}$ The collapse of credit and shaken confidence could depress the investment (and consumption) spending, which would move the $I S$ curve to the left. Moreover, if the misallocation of resources is substantial, scars on the economy may be permanent in the form of lower long-run growth in potential output. The eventual state of the economy is therefore hard to determine.

Although the Austrian authors would agree that money is neutral in the sense that it can never permanently increase output and that the major outcome of money expansion is price inflation, monetary manipulation is not neutral in the sense that it leaves the state of real variables unaffected. The long-run effect of the money increase, which was directed to stabilize the price level, is the misallocation of real resources and a loss of potential output.

\section{The Mainstream Perspective}

The Austrian exposition is at variance with the mainstream wisdom of beneficial effects of price level stabilization. The leading New Keynesian Woodford (2003, p. 5) stressed that inflation or deflation is a "symptom of systematic imbalances in resource allocation" and that "instability of the general level of prices causes substantial real distortions leading to inefficient variation both in aggregate employment and output and in the sectoral composition of economic activity" (ibid.). With respect to positive inflation, Woodford focussed on its harmfulness owing to the existence of price stickiness:

"When prices are not constantly adjusted, instability of the general level of prices creates discrepancies between relative prices owing to the absence of perfect synchronization in the adjustment of the prices of different goods. These relative-price distortions lead in turn to an inefficient sectoral allocation of resources, even when the aggregate level of output is correct." (Woodford, 2003, p. 12)

It is notable that Woodford put emphasis on the (mis)allocation of resources, the role of relative prices, and other topics stressed by the Austrian authors. Woodford (2003, p. 5) in the opening chapter of his book, which became one of the most popular in mainstream economics, even mentioned Hayek as one of the economists that followed, as well as Woodford himself, the Wicksellian tradition. It might be therefore suggested that the New Synthesis of the Real Business Cycle theory and New Keynesianism praised by modern mainstream authors could integrate some of the ideas of Hayek and Mises.

However, this integration is not as straightforward as it might seem at first glance. Woodford (2003, p. 13) explicitly said that the policy of price level stabilization will eventually eliminate the output gap, which is at variance with the Austrian theory. Moreover, in one of his specific models, it is shown that under normal conditions the zero-

$7 \quad$ The attempt to overcome "good deflation", which could accompany technological progress, ends up in "bad deflation" (or secondary deflation) due to the partial collapse of the deposit superstructure and the resulting fall in the aggregate demand. 
inflation target is optimal (Eggertsson and Woodford, 2003, p. 167), even though it is suggested that a self-sustained deflation might be also an equilibrium outcome in the model (ibid., p. 194). The rate of deflation in that equilibrium is equal to the rate implied by the Friedman rule. On the other hand, Jung et al. (2005, p. 820) stressed that this specific deflation is inferior to the zero inflation target due to the existence of the zero lower bound on the nominal interest rate.

Other New Keynesians prefer a low, yet positive, rate of inflation to zero inflation (Akerlof et al., 1996). There is no need to list arguments that appeared in the literature supporting this proposal. The common practice of modern central banks targeting a positive (not zero) rate of inflation is a direct outcome of this theory. Interestingly, Gordon in the discussion in Akerlof et al. (1996) pointed out that in the 19th century, economic growth was accompanied by a general decline in prices. Nonetheless, Blinder and Reis (2005) in praising the genius of Alan Greenspan explicitly wrote that more rapid growth in potential output requires loose monetary policy to speed up the movement of actual output on the new potential level. ${ }^{8}$

The IS-LM-Y* and the AD/AS models will be used to show the core of the argument of mainstream economics, and the difference between the New Keynesian and the Austrian theory. The optimum behaviour of an economy that is growing at some positive rate, and in which the natural rate of interest is constant, is depicted in Figure 8. Panel (a) shows that the increase in aggregate demand is as large as the increase in aggregate supply. The economy smoothly moves to the new equilibrium. The actual output is equal to the potential output, and the price level (or inflation in more complex models) is stabilized. There is no disturbance in output or the interest rate; there is no Austrian-style boom-bust cycle.

Similar pictures can be found in elementary texts that were designed to introduce basic tenets of the New Keynesian model (Benigno, 2009; Mankiw, 2009). The economic logic behind the smooth transition to the new potential level is described within the framework of this model. With a permanently higher level of income, people feel richer and hence they consume more. This is the reason for the shift of the $A D$ curve, which is, however, derived from the New Keynesian $I S$ curve and a simple monetary policy rule of the Taylor type.

In the New Keynesian literature, there is no reference to money in this process (McCallum, 2001; Woodford, 2008). ${ }^{9}$ However, the omission of money is rather disturbing for our analysis since the total value of aggregate nominal expenditures $(P Y)$ cannot increase without the expansion of the money supply $M$ or the velocity of circulation $V$. Moreover, consumption is endogenous in this model as well as is output, and the consumption increase is hidden in the increase of output. Thus, consumption as the endogenous component of $Y$ cannot shift the entire $A D$ curve.

The $A D$ curve in the New Keynesian framework contains one important component a monetary policy rule. Within this rule, the central bank sets the interest rate in accordance

8 According to Blinder and Reis (2005), the optimal monetary policy in this situation is to allow a temporary decrease in the unemployment rate below the natural level rather than lower inflation.

9 When the transaction technology for money is included, the $I S$ curve depends also on real money balances. However, the inclusion of money in this form has no significant impact on the model (McCallum, 2001). 
with its goals and the state of the economy. The money supply is automatically adjusted to any demand for money for the given rate of interest - the money supply is endogenous. As a result, the mainstream New Keynesian reasoning more consistent with the basic macroeconomic principles could be as follows: with a permanently increasing potential output, the real demand for money is rising. The central bank automatically accommodates this higher demand for money by the increase in the money supply, keeping the interest rate at a constant level ( $r_{C B}$ in panels (b) and (c) in Figure 8).

\section{Figure 8 | Balanced Growth Path and Price Level Stabilization in the New Keynesian Model}

(a)

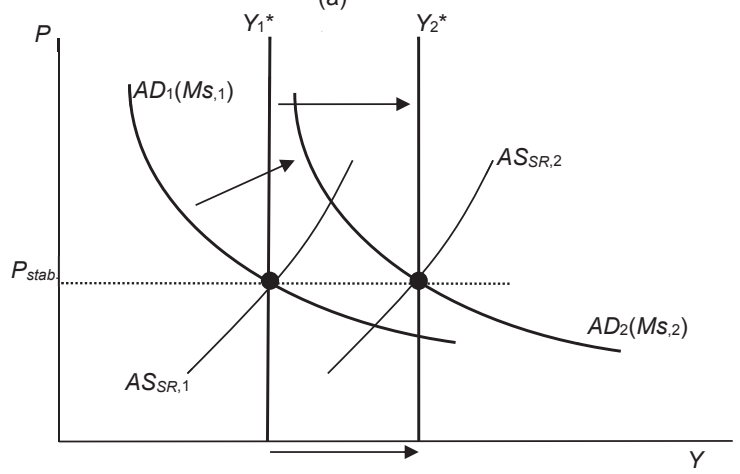

(b)

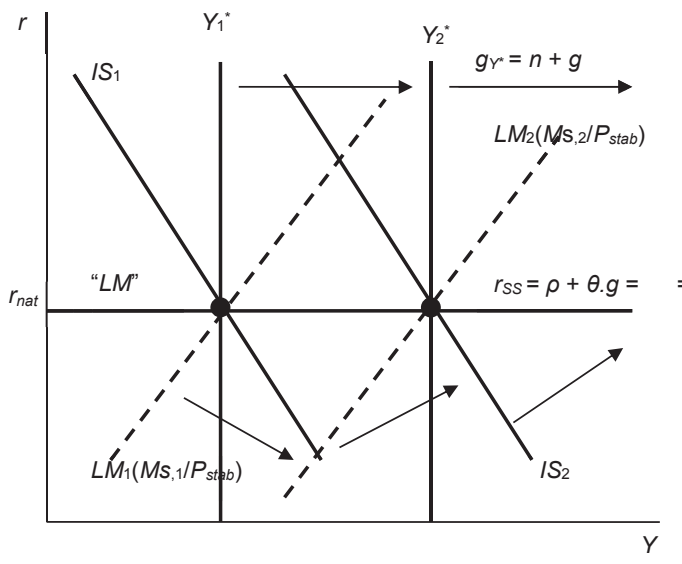

(c)

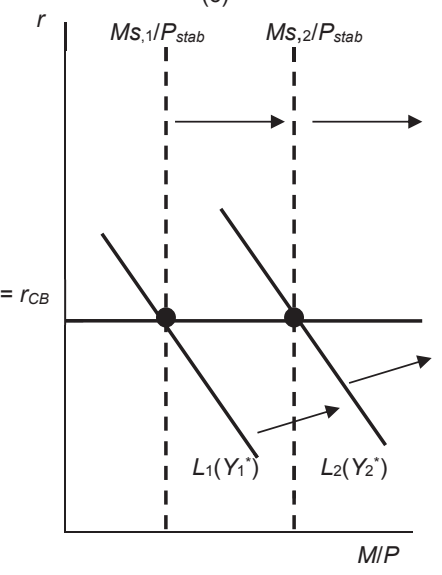

Source: Own construction

The money market representation of this process is the same as in panel (b) of Figure 6. The only difference is that the vertical real money supply curve shifts to the right due to the expansion of the nominal money supply, not owing to the decrease in the price level, which is constant. In panel (c) of Figure 8, the endogenous character of the money supply in the money market is represented by a horizontal line, in panel (b) reflected in a horizontal 
"LM" curve. The interest rate is set by the central bank; however, in perfect conformity with the natural level. The expansion of the nominal money supply is hidden in the model.

The increase in the money supply in the New Keynesian (NK) model is perfectly neutral with respect to the growing economy. It is automatically absorbed by a higher demand for money that stems from expanding real incomes. Price level is stabilized without any boom-bust pattern envisioned by the Austrian theory. In the New Keynesian terms, there is no output gap, and no better policy the central bank can conduct.

The mainstream perspective of the policy suggested by Hayek can be also deduced. Suppose that the economy is growing, but the money supply is fixed and exogenous, not endogenous as in the NK model. Assume that the price level is rigid even though the potential output is growing due to technological progress. Figure 9 depicts this situation in the ISLM-Y* and AD/AS models.

Figure 9 | Unrealised Growth of Output due to the Fixed Price Level

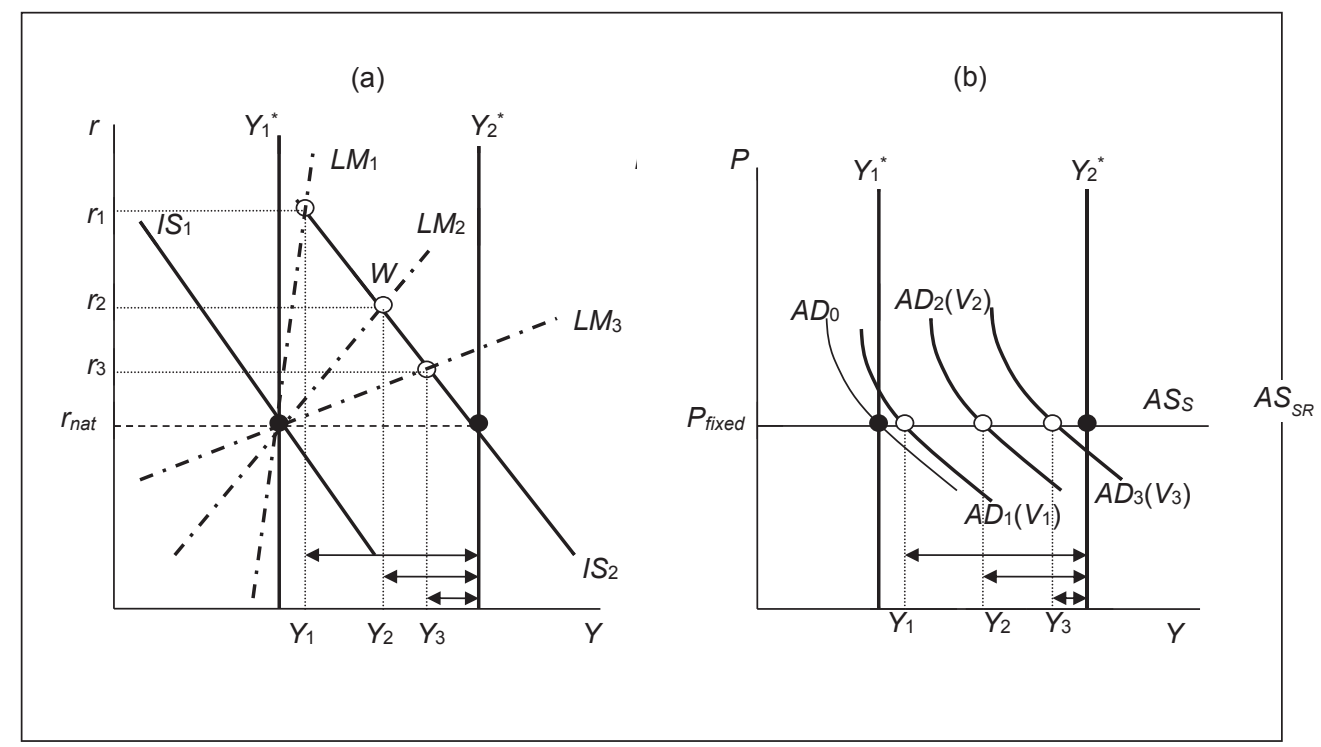

Source: Own construction

The economic growth causes both the rightward shift of the $Y^{*}$ curve and the $I S$ curve. However, the (short-run) equilibrium of the economy depends on the slope of the $L M$ curve. At this moment, the sensitivity of the demand for money to the interest rate plays a crucial role. It will decide how far the actual output will be from the new potential output. The flatter the $L M$ curve, the smaller the difference between the actual and the natural rate of interest, and hence the lower the output gap. If both the money supply and the price level are fixed, the higher demand for money can be satisfied only by a movement of the interest rate. If the demand for money is very sensitive to the interest rate $\left(L M_{3}\right)$, an increase in the rate of interest drastically reduces the required amount of money balances. People dissolve 
part of their "cash" reserves, which may "finance" the increase in output. In other words, the increase in natural output is accompanied by a significant increase in velocity $\left(V_{3}\right)$, which is reflected by a considerable shift of the $A D$ curve $\left(A D_{3}\right)$. The economy ends up very close to the new potential level $\left(Y_{3}\right)$.

On the other hand, when the demand for money is almost insensitive to changes in the interest rate $\left(\mathrm{LM}_{1}\right)$, the interest rate rises to very high levels $\left(r_{1}\right)$, and the economy is stuck close to the previous level of output $\left(Y_{1}\right)$. This situation, in which the resulting negative output gap is very large $\left(Y_{1}-Y_{2} *\right)$, is paradoxical - technological progress allows higher output in the economy; yet this potential is not realised due to the fixed price level, fixed money supply, and stable velocity.

Figure 9 may be also used to examine the Wicksellian interpretation of this process. The actual rate of interest is above the natural rate $\left(e . g . r_{2}>r_{n a t}\right)$. In the New Keynesian theory, this implies a negative output gap $\left(Y_{2}<Y_{2}^{*}\right)$ (see Appendix 2). In the long run, the negative output gap should induce a decrease in the price level, which is in perfect harmony with the Wicksell predictions. Thus, it seems that the Hayek critique of Wicksell was not perfectly accurate, as both theories may be consistent. They only refer to a different time horizon. The Hayek theory of the declining price level and of the equality between the actual interest rate and the natural interest rate is designed for a smooth process in the framework with a perfectly flexible price level, in which the growing potential output is immediately reflected in a lower price level. The Wicksell theory, on the other hand, stresses the point at which the actual interest rate is above the natural rate (point $W$ in Figure 9 ), creating pressures on the decline in the price level in the future. It can be deduced that Wicksell's approach is based on the short-run inflexibility of prices, even though this "short run" may be an infinitely short period of time. As a result, it is rather hard to decide whether the Hayek objection to Wicksell's theory is justifiable. Both economists may describe the same dynamic phenomenon; yet, from a different point of view. If this perspective is correct, then both theories could be reconciled.

On the other hand, the simple New Keynesian model presented in Appendix 2 may give more credit to the Hayek approach. The NK IS curve and the NK PC may be used to reinterpret the Wicksell idea that the price level is rising or falling when the interest rate gap $\left(r-r_{n a t}\right)$ emerges. Substituting (2.1) into (2.2) from Appendix 2 yields:

$$
\pi=\pi^{e}-\alpha \beta\left(r-r_{n a t}\right)
$$

Equation (2.4) can be called the Wicksell equation. It states that if the actual real interest rate $r$ is higher than the natural rate of interest $r_{n a t}$, the actual inflation rate $\pi$ will be below the expected inflation rate $\pi^{e}$. This equation also implies that the equality between the actual and the natural rate of interest is consistent with an increasing or a decreasing price level if this increase or decrease was correctly expected. Thus, if the central bank is able to hit its inflation target of $2 \%$, and this rate is anticipated by the general public, the price level will be rising without an interest-rate gap. Accordingly, under the Hayek framework, if the secular deflation is built in people's expectations, the price level might be declining even though the interest rate is at the natural level. This simple equation therefore gives 
credit to the Hayek critique of Wicksell since the famous Wicksellian conclusions are valid only for zero expected inflation. ${ }^{10}$

When the assumption of a perfectly fixed price level from Figure 9 is relaxed, the AS curve will be upward sloping rather than horizontal. Mainstream economics may still suggest that not all prices are instantly adjusted when the potential output is growing over time. Figure 10 displays that in the short run, the economy is trapped in quasi-recession (point B). The output is growing; however, its growth is below potential due to the non-adjustment of some prices. Assuming flexible prices in the long run, the economy should end up at the new potential level with a lower price level, as is suggested by the Austrian theory in Figure 2 and by point $D$ in Figure 10. Nonetheless, there is a transition period of below-potential growth that could be speeded up if the money supply was allowed to increase.

Figure 10 | Quasi-Recession due to Imperfect Adjustment in Prices

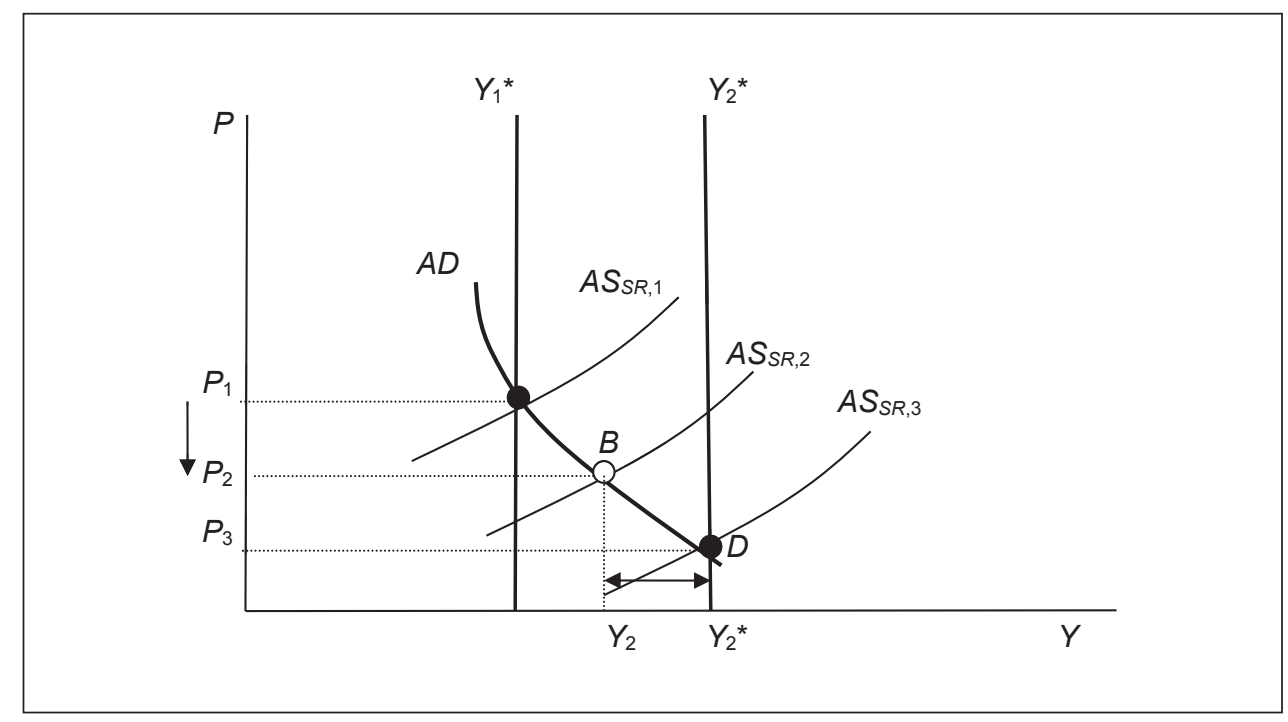

Source: Own construction

\section{Austrian Critique of the New Keynesian Views}

The key dividing point between the Austrian model and mainstream economics about optimal monetary policy in a growing economy is whether the higher real demand for money, which emerges due to rising potential output and real incomes, is to be satisfied by a reduction in the price level or by a higher nominal money supply. Austrians prefer the former since the latter may lead to the boom-bust cycle. New Keynesians would recommend

10 Bertil Ohlin in his Introduction to Wicksell (1936) indicated that in later works, Wicksell partly modified his position held in earlier writings by stressing the role of expectations. Equation (2.4) is an explicit solution of the problem in the Wicksell theory. 
the latter because the former could result in quasi-recession. In the Austrian vision, money is neutral with respect to the real economy if it is not increased in the situation of expanding output, whereas New Keynesians believe in the rigidity of prices that may cause serious problems when the money supply is not appropriately adjusted.

Figure 11 | Menu Cost Model and the Reduction in Costs

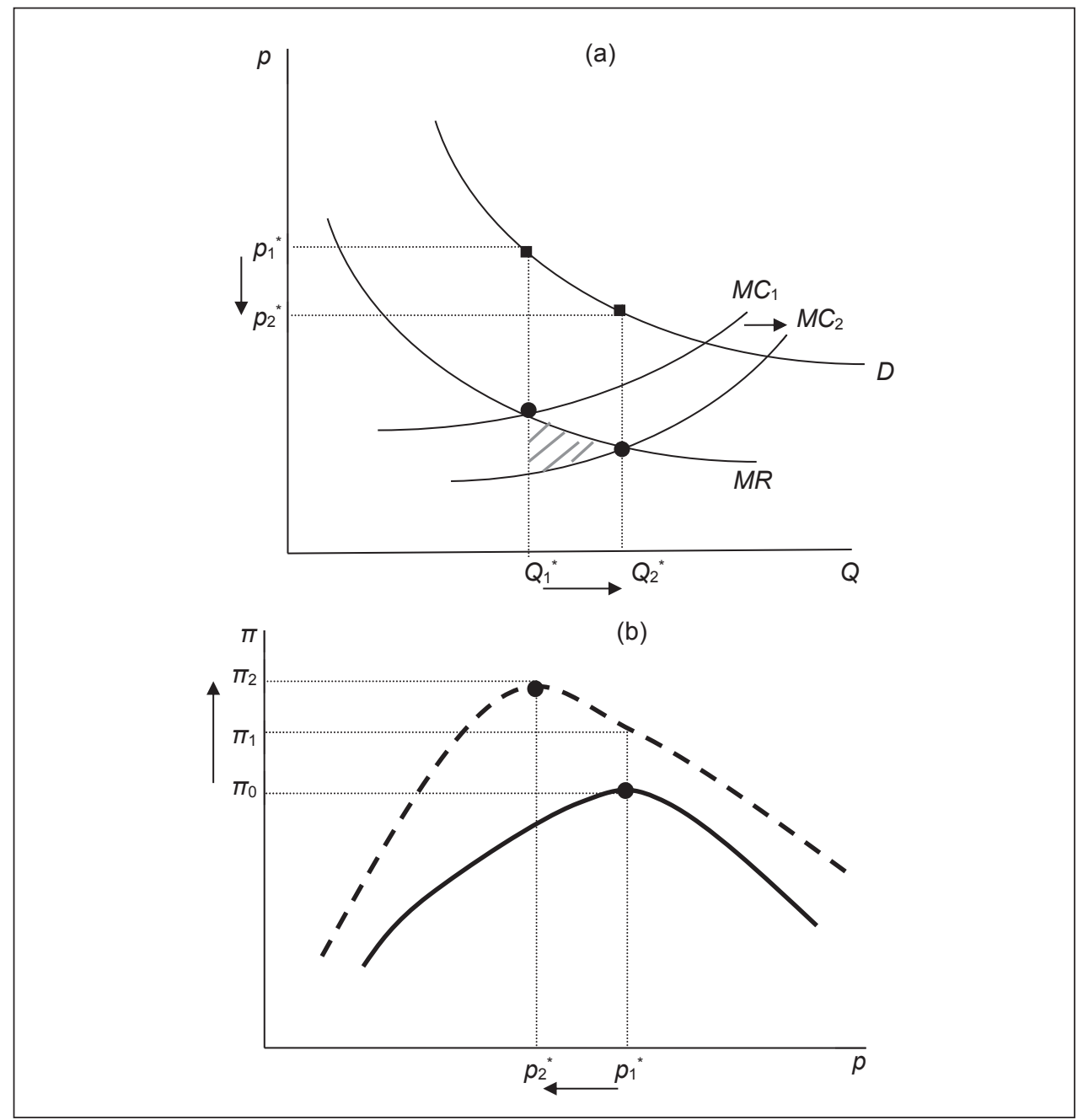

Source: Own construction

Let us present arguments that may support the Austrian vision and cast some doubts on the New Keynesian theory. The core of the problem is the demand for money. When people demand more money, it might not be a one-sided transaction. In the period of growing output, more goods are offered on the market. But this new supply of goods automatically 
means a higher demand for money (Rothbard, 2004; A. Fisher, 1935). Moreover, a larger supply of goods can be realized in the markets only for lower prices. As a result, the increase in the supply of goods, a higher demand for money, and a lower price level are three sides of the same phenomenon. Hence, the smooth process introduced in Figure 6 may be automatic in the real world. If it is accepted that a higher quantity of goods on the individual market can be sold for a lower price, the same should hold at the macroeconomic level higher aggregate output is sold for lower prices. ${ }^{11}$

A wide range of New Keynesian models was developed to explain rigidity of prices (Mankiw and Romer, 1991). One of the most popular is the Mankiw (1985) menu cost model. It is based on the idea that the economy is composed of many imperfectly competitive firms. Figure 11 shows a simplified version of this model. It is argued that an imperfectly competitive firm may not reduce the price after a negative demand shock due to the existence of costs associated with this act of price adjustment (Romer, 2006).

According to Selgin (1997), however, the motivation of firms to adjust prices when they face reduction in costs may differ from the situation of contracting demand. It would be irrational not to sell a larger quantity of goods, produced due to improvements in technology. Reduction in demand might be unexpected, however, plans designed by firms should consider better production possibilities along with the costs of adjusting prices, once larger production is to be sold. As a result, there might be a significant asymmetry in the price adjustment. If the firm faces a reduction in demand, it might be reluctant to lower its price. After all, it will suffer from lower profitability. On the other hand, reduction in costs is a different matter that first, should have been taken into account in global decision-making processes of the firm in the past, and second, is accompanied by higher profitability.

Figure 11 shows the potential loss from the non-adjustment of the individual price after the reduction in costs (from $M C_{1}$ to $M C_{2}$ in panel (a)) caused by technological progress, which also shifts the profit curve outwards (dashed curve in panel (b)). The shaded triangle in panel (a), representing unrealized profits due a fixed individual price (and hence quantity since the demand curve does not move), is to be compared with the "menu costs". If the former exceeds the latter, the firm should decrease the price. In such a case, the firm operates at the profit maximizing $\left(\pi_{2}\right)$ quantity $\left(\mathrm{Q}_{2}{ }^{*}\right)$ and price $\left(p_{2}{ }^{*}\right.$ in panel (b)). If the firm does not adjust the price, the profit will still be larger than before by distance $\left(\pi_{1}-\pi_{0}\right)$. However, it would be rather surprising if improved technologies were not realized in the expanded production.

Thus, it may be much easier for the firm to reduce the price when it faces saving in costs in contrast to the contraction in demand. The macroeconomic implication is that

11 The argument of postponed consumption due to an anticipated decrease in the price level is not relevant. An expected deflation should lower the nominal interest rate in conformity with the Fisher effect. Thus, the real interest rate stays at the natural level with no impact on the optimal intertemporal allocation of consumption. Only the zero lower bound on the nominal interest rate may lead to problems in this connection. Hence, the argument of Fisher (1933) about the debtdeflationary depression is not valid, if the deflation is perfectly anticipated, as is assumed in the analysis above. The Fisher (1933, p. 342) distress selling due to debt liquidation is much more likely under the unexpected deflation caused by negative aggregate demand shocks. 
the downward shift of the $A S_{S R}$ curve in Figure 10 is smooth, so the economy may readily reach the new potential output with a lower price level. On the other hand, the $A S_{S R}$ curve might be inflexible and flat as far as the fall in aggregate demand is concerned.

\section{Concluding Remarks}

This article introduced a growing economy in which the natural rate of output was initially on a smooth path that was then disturbed by a deliberate manipulation with the money supply aimed at stabilization of the price level. The presented Austrian theory highlighted business-cycle repercussions connected to this effort. The Hayekian theory in this article also stressed that the impact of the monetary sector on the real part of the economy is never neutral even in the very long run, in which, as is believed by the natural rate hypothesis, the economy is driven by forces of economic growth and the influence of money is usually disregarded.

The paper shows that recommendations of mainstream economics for monetary authorities in the period of economic growth are exactly the opposite of the Austrians: the money supply should be increasing along with growth in potential output. The economy may automatically absorb money it needs from the central bank for a fixed interest rate. This new money is then neutral with respect to the real economy. An insufficient increase in the nominal money supply compared with a growing demand for money may lead to problems in the real economy - the real output will grow at a lower rate than it could.

The conclusion of this article is that the objections of mainstream economics against a declining price level ought to be reconsidered as far as growth in aggregate supply is concerned. Models of price rigidity are applicable to falls of aggregate demand rather than to a secular growth of potential output, whose impact on the structure of prices might be better understood in the Hayekian framework.

\section{Appendix $1 \quad$ IS-LM-Y* model}

The loanable funds equilibrium between investment and saving can be represented as follows:

$$
\begin{gathered}
S(r, Y)=I(r, A) \\
S\left(i-\pi^{e}, Y\right)=I\left(i-\pi^{e}, A\right)
\end{gathered}
$$

where $r$ is the real interest rate, which is equal, using the Fisher effect, to $r=i-\pi^{e}$, where $i$ is the nominal interest rate, and $\pi^{e}$ is the expected inflation rate. The level of technologies $A$ is the major shifter of the investment curve, whereas real income $Y$ of the saving curve.

In a closed economy without government, the disposable income is saved $S$ or consumed $C$ :

$$
Y=C+S
$$

Total output, which equals total income, has the form of final consumption goods or investment goods: 


$$
Y=C+I
$$

Thus, equation (1.1) is derived from (1.2) and (1.3), and it can be used to find the slope of the IS curve, here interpreted as all combinations of real income and real interest rate consistent with the equilibrium on the loanable funds market $(S=I)$. Since the money market will be defined for the nominal interest rate, we use (1.1b). Its total differential is:

$$
S_{r} d i-S_{r} d \pi^{e}+S_{Y} d Y=I_{r} d i-I_{r} d \pi^{e}+I_{A} d A
$$

Lower subscripts denote partial derivatives. By assumption, $S_{r}, S_{Y}, I_{A}$ are positive and $I_{r}$ is negative. $\pi^{e}$ and $A$ are shifters of the $I S$ curve, so they are constant in finding the slope of the $I S$ curve, which is derived in space $(Y, i)$ from (1.4) as follows:

$$
\left.\frac{d Y}{d i}\right|_{I S}=\frac{I_{r}-S_{r}}{S_{Y}}<0
$$

The slope of the $I S$ curve is negative, and $1 / S_{Y}$ is the Keynesian multiplier.

The money market equilibrium is:

$$
\frac{M}{P}=L(i, Y)
$$

$M$ is the nominal money supply, $P$ is the price level, and $L(\bullet)$ is the real demand for money, which depends negatively on the nominal interest rate $i$ and positively on real income $Y$. The slope of the $L M$ curve (keeping the supply of real money balances $M / P$ constant) is positive, and it is derived from (1.6) as follows:

$$
\begin{gathered}
0=L_{i} d i+L_{Y} d Y \\
\left.\frac{d i}{d Y}\right|_{L M}=-\frac{L_{Y}}{L_{i}}>0
\end{gathered}
$$

The last equation of the model IS-LM-Y* in the main text is the vertical curve of the potential output $Y^{*}$, which depends positively on the amount of capital $K$, labour $N$, and the labouraugmenting technological progress $A$ :

$$
Y^{*}=F(K, A N)
$$

The aggregate-demand relationship between $P$ and $Y$ is derived from the $I S$ curve (1.1b) and the $L M$ curve (1.6). The total derivative of (1.1b) with respect to the price level $P$ is:

$$
S_{r} \frac{d i}{d P}+S_{Y} \frac{d Y}{d P}=I_{r} \frac{d i}{d P}
$$

(1.10) uses the fact that $P$ does not affect $A$ or $\pi^{e}$, and it leads to:

$$
\frac{d Y}{d P}=\frac{I_{r}-S_{r}}{S_{Y}} \frac{d i}{d P}
$$


The total derivative of the money market equilibrium (1.6) with respect to $P$ yields:

$$
-\frac{M}{P^{2}}=L_{i} \frac{d i}{d P}+L_{Y} \frac{d Y}{d P}
$$

Thus:

$$
\frac{d i}{d P}=\left(-\frac{M}{P^{2}}-L_{Y} \frac{d Y}{d P}\right) \frac{1}{L_{i}}
$$

Substitution of (1.13) into (1.11), roughly speaking $L M$ into $I S$, gives us the slope of the AD curve, which is negative:

$$
\begin{gathered}
\frac{d Y}{d P}=\frac{I_{r}-S_{r}}{S_{Y}}\left(-\frac{M}{P^{2}}-L_{Y} \frac{d Y}{d P}\right) \frac{1}{L_{i}} \\
\frac{d Y}{d P}+\frac{I_{r}-S_{r}}{S_{Y}} \frac{L_{Y}}{L_{i}} \frac{d Y}{d P}=-\frac{M}{P^{2}} \frac{I_{r}-S_{r}}{S_{Y}} \frac{1}{L_{i}} \\
\frac{d Y}{d P} \frac{S_{Y} L_{i}+\left(I_{r}-S_{r}\right) L_{Y}}{S_{Y} L_{i}}=-\frac{M}{P^{2}} \frac{I_{r}-S_{r}}{S_{Y}} \frac{1}{L_{i}} \\
\left.\frac{d Y}{d P}\right|_{A D}=-\frac{M}{P^{2}} \frac{I_{r}-S_{r}}{S_{Y} L_{i}+\left(I_{r}-S_{r}\right) L_{Y}}<0
\end{gathered}
$$

It can be shown that the elasticity form of $(1.14 \mathrm{~d})$ is as follows: ${ }^{12}$

$$
\left.e_{Y, P}\right|_{A D}=-\frac{1}{\frac{e_{S, Y}}{\frac{i}{r}\left(e_{I, r}-e_{S, r}\right)} e_{L, i}+e_{L, Y}} \leq 0
$$

For the real interest rate, which is used in the main text, (1.14e) leads to:

$$
\left.e_{Y, P}\right|_{A D}=-\frac{1}{\frac{e_{S, Y}}{\left(e_{I, r}-e_{S, r}\right)} e_{L, r}+e_{L, Y}} \leq 0
$$

Higher sensitivity (elasticity) of the demand for money to the nominal interest rate $L_{i}\left(e_{L, i}\right)$ leads to a steeper AD curve, whereas zero interest-sensitivity of the Cambridge money demand function $L \equiv M^{d} / P=k Y$, where $L_{i}=O\left(e_{L, i}=0\right)$ and $L_{Y}=k\left(e_{L, Y}=1\right)$, results in unitary elasticity of the $A D$ curve $e_{Y, P}=-1$. This specific case is consistent with the constantvelocity assumption in the main text.

12 This procedure is rather long and can be sent upon request. 


\section{Effects of technological progress}

The key shifter in the main text was the technological progress $A$. It shifts the potential output to the right (see 1.9), which should create strong pressures on the decline in the price level when the demand for money is very sensitive to the interest rate (see 1.14d).

However, the following exposition shows that $A$ might be also a shifter of the $A D$ curve if the demand for money depends on the interest rate (unstable velocity). The total derivative of the $I S$ curve (1.1b) with respect to $A$ is:

$$
S_{r} \frac{d i}{d A}+S_{Y} \frac{d Y}{d A}=I_{r} \frac{d i}{d A}+I_{A}
$$

The impact of the change in $A$ on the $I S$ curve depends on the sensitivity of the investment spending on the change in technologies $I_{A}$ and on the expenditure multiplier $1 / S_{Y}$ :

$$
\frac{d Y}{d A}=\frac{I_{r}-S_{r}}{S_{Y}} \frac{d i}{d A}+\frac{I_{A}}{S_{Y}}
$$

The total derivative of the $L M(1.6)$ with respect to $A$ gives us:

$$
\begin{gathered}
0=L_{i} \frac{d i}{d A}+L_{Y} \frac{d Y}{d A} \\
\frac{d i}{d A}=-\frac{L_{Y}}{L_{i}} \frac{d Y}{d A}
\end{gathered}
$$

Inserting (1.18) into (1.16) yields:

$$
\begin{gathered}
\frac{d Y}{d A}=\frac{I_{r}-S_{r}}{S_{Y}}\left(-\frac{L_{Y}}{L_{i}} \frac{d Y}{d A}\right)+\frac{I_{A}}{S_{Y}} \\
\frac{d Y}{d A}\left(1+\frac{I_{r}-S_{r}}{S_{Y}} \frac{L_{Y}}{L_{i}}\right)=\frac{I_{A}}{S_{Y}} \\
\frac{d Y}{d A} \frac{S_{Y} L_{i}+\left(I_{r}-S_{r}\right) L_{Y}}{S_{Y} L_{i}}=\frac{I_{A}}{S_{Y}} \\
\left.\frac{d Y}{d A}\right|_{P_{-} \text {const }}=\frac{I_{A} L_{i}}{S_{Y} L_{i}+\left(I_{r}-S_{r}\right) L_{Y}} \geq 0
\end{gathered}
$$

The elasticity form of $(1.19 \mathrm{~d})$ is:

$$
\left.e_{Y, A}\right|_{P_{-} \text {const }}=\frac{e_{I, A} e_{L, i}}{e_{S, Y} e_{L, i}+\frac{i}{r}\left(e_{I, r}-e_{S, r}\right) e_{L, Y}} \geq 0
$$


Alternatively:

$$
\left.e_{Y, A}\right|_{P_{-} \text {const }}=\frac{e_{I, A} e_{L, r}}{e_{S, Y} e_{L, r}+\left(e_{I, r}-e_{S, r}\right) e_{L, Y}} \geq 0
$$

(1.19d) determines the horizontal shift of the $A D$ curve due to greater $A$, i.e. the effect of $A$ on $Y$ for a given $P$. (1.19d) also proves that the change in $A$ has no impact on $A D$ only if the demand for money is insensitive to the interest rate $\left(L_{i}=0\right.$, stable velocity). If $L_{i}<0$ and velocity is therefore unstable, improvements in technologies may shift not only the $Y^{*}$ curve but also the AD curve. The impact on the price level $P$ is then not clear. However, for $L_{i}<0$ the $A D$ is steeper, which creates strong pressures on the decline in $P$ when $Y^{*}$ rises.

The following proof demonstrates that the balanced growth path (BGP) creates pressures on the decline in the price level regardless of $L_{i}$, even though both $Y^{*}$ and $A D$ may be shifted to the right. The Austrian conclusion from the main text, predicting the decline in $P$ when technologies are improving, holds generally. The crucial role is played by $L_{Y}$, as is presented below.

On the BGP, the natural real interest rate $r^{*}$ is constant and $Y^{*}$ is growing at the rate $n+g$. In the very long run, even the nominal interest rate $i$ should be constant due to anchored inflation (deflation) expectations. Thus, from the three key equations of the model: IS (1.1a), LM (1.6), and the potential output $Y^{*}$ determination (1.9), the $L M$ will give us the crucial answer since the balanced growth of $Y^{*}$ has an equal impact on $S$ and $I$ for the given constant interest rate.

The total differential of the $L M$ curve $M=P L(i, Y)$ is as follows:

$$
d M=L(i, Y) d P+P\left(L_{i} d i+L_{Y} d Y\right)
$$

On the BGP, $d i=0, d Y>0$ and the Austrian recommendation is $d M=0$. Thus, (1.20) results in:

$$
\left.\frac{d P}{d Y}\right|_{i_{-} \text {const }}=-\frac{P L_{Y}}{L(i, Y)}
$$

(1.21) can be used to show that the percentage change in $P$ due to a $1 \%$ growth in $Y^{*}\left(e_{P, Y}\right)$ on the BGP is directly related to the (negative of the) income elasticity of the real demand for money $e_{L, Y}$ :

$$
\begin{gathered}
\left.\left.e_{P, Y}\right|_{i_{-} \text {const }} \equiv \frac{d P}{d Y} \frac{Y}{P}\right|_{i_{-} \text {const }}=-\frac{P L_{Y}}{L(i, Y)} \frac{Y}{P} \\
\left.\left.e_{P, Y}\right|_{i_{-} \text {const }} \equiv \frac{d P}{d Y} \frac{Y}{P}\right|_{i_{-} \text {const }}=-L_{Y} \frac{Y}{L(i, Y)} \equiv-e_{L, Y}
\end{gathered}
$$

The Cambridge demand for money $L=k Y$ results in the unit-elastic $A D$ and in no shift of $A D$ when $A$ (and therefore $Y^{*}$ ) is increasing (see $1.19 \mathrm{~d}$ ), leading to a $1 \%$ fall in $P$ for every $1 \%$ increase in $Y^{*}$. The textbook Keynesian demand for money $L=k Y-h i$, where $L_{i}=-h<0$, results in the shift of both $A D$ (see 1.19d) and $Y^{*}$ when $A$ is increasing. 
However, the income elasticity of $L$ is then:

$$
e_{L, Y} \equiv L_{Y} \frac{Y}{L(i, Y)}=k \frac{Y}{k Y-h i} \geq 1
$$

So for an interest-sensitive demand for money, the elasticity (1.23) is greater than one. According to (1.22b), a $1 \%$ balanced growth in $\mathrm{Y}^{*}$ (due to increasing $A$ ) results in a greater than $1 \%$ fall in $P$, even though $A D$ is being shifted as well as $\mathrm{Y}^{*}$ (see $1.19 \mathrm{~d}$ ). The reason is that the shift in $\mathrm{Y}^{*}$ is greater than that of $A D$, and the $A D$ curve is very steep (see $\left.1.14 \mathrm{~d}\right){ }^{13}$ In other words, the velocity is spontaneously falling when $Y^{*}$ is growing.

The demand for money of the textbook Baumol-Tobin model $L=(\gamma Y / 2 i)^{1 / 2}$, where $\gamma$ is the real cost to exchange illiquid assets to money, exhibits the income elasticity of $1 / 2$, and the interest elasticity of $-1 / 2$. According to (1.22b), the fall in $P$ would be just $0.5 \%$ in case of a $1 \%$ growth in $Y^{*}$ (caused by greater $A$ ). For this case, velocity spontaneously grows. The McCallum (2001, p. 149) model of the demand for money has the income elasticity of one. Thus, a priori there is no reason to expect any particular behaviour of $V$ in the economy with increasing $A$ (and $Y^{*}$ ), which confirms the conclusion from the main text.

\section{Appendix 2 Basics for the Wicksell equation}

The basic structure of the New Keynesian (NK) model, ignoring shocks, is as follows: ${ }^{14}$

$$
\begin{gathered}
y=y^{*}-\alpha\left(r-r_{n a t}\right) \\
\pi=\pi^{e}+\beta\left(y-y^{*}\right) \\
i_{C B}=r_{n a t}+\pi+\theta_{\pi}\left(\pi-\pi^{T}\right)+\theta_{y}\left(y-y^{*}\right)
\end{gathered}
$$

Equation (2.1) is the NK IS curve that states that the positive output gap emerges $\left(y-y^{*}>0\right)$ when the actual real rate of interest $r$ is lower than the natural level $r_{n a t}$. Equation (2.2) is the NK Phillips curve that implies that the actual inflation rate $\pi$ depends on the expected inflation rate $\pi^{e}$ and on the output gap. Expression (2.3) is the Taylor rule that prescribes the interest-rate policy for the central bank. The interest rate of the central bank $i_{C B}$ should respond to the change in the real natural rate of interest, to the output gap, and to the deviation of inflation $\pi$ from the inflation target $\pi^{T}$.

13 Note that (1.21) and (1.22b) are about $\mathrm{d} P / \mathrm{d} Y$, whereas (1.14d) describes $\mathrm{d} Y / \mathrm{d} P$.

$14 y$ is a natural logarithm of $Y$. See Mankiw (2009). The rigorous derivation of the New Keynesian model, especially the $I S$ curve in the form: this period output gap depends on the expected next period output gap and on the difference between the actual real interest rate and the natural real interest rate, can be found in Woodford (2003) and Galí (2008). 


\section{References}

Akerlof, G. A., Dickens, W. R., Perry, G. L. (1996). The Macroeconomics of Low Inflation. Brookings Papers on Economic Activity, 27(1), 1-76, http://doi.org/10.2307/2534646

Amato, J. D. (2005). The Role of the Natural Rate of Interest in Monetary Policy. CESifo Economic Studies, 51(4), 729-755, http://doi.org/10.1093/cesifo/51.4.729

Atkeson, A., Kehoe, P. J. (2004). Deflation and Depression: Is There an Empirical Link? The American Economic Review, 94(2), 99-103, http://doi.org/10.1257/0002828041301588

Beckworth, D. (2008). Aggregate Supply-Driven Deflation and Its Implications for Macroeconomic Stability. Cato Journal, 28(3), 363-384.

Benigno, P. (2009). New-Keynesian Economics: An AS-AD View. National Bureau of Economic Research. Working Paper No. 14824, http://doi.org/10.3386/w14824

Blinder, A. S., Reis, R. (2005). Understanding the Greenspan Standard. Proceedings, Federal Reserve Bank of Kansas City, 11-96.

Bordo, M. D., Lane, J. L., Redish, A. (2004). Good versus Bad Deflation: Lessons from the Gold Standard Era. National Bureau of Economic Research. Working Paper No. 10329, http://doi. org/10.3386/w10329

Bordo, M. D., Filardo, A. (2004). Deflation and Monetary Policy in a Historical Perspective: Remembering the Past or Being Condemned to Repeat It? National Bureau of Economic Research. Working Paper No. 10833, https://doi.org/10.3386/w10833

Borio, C., Erdem, M., Filardo, A., Hofmann, B. (2015). The Costs of Deflations: A Historical Perspective. BIS Quarterly Review, Bank for International Settlements, March.

Bradford, F. A. (1929). Some Aspects of the Stable Money Question. The Quarterly Journal of Economics, 43(4), 667-696, https://doi.org/10.2307/1882963

Cassel, G. (1928). The Rate of Interest, the Bank Rate, and the Stabilization of Prices. The Quarterly Journal of Economics, 42(4), 511-529, https://doi.org/10.2307/1882532

Cochran, J. P., Call, S. P., Glahe, F. R. (2003). Austrian Business Cycle Theory: Variations on a Theme. The Quarterly Journal of Austrian Economics, 6(1), 67-73, https://doi.org/10.1007/ s12113-003-1013-3

Eggertsson, G. B., Woodford, M. (2003). The Zero Bound on Interest Rates and Optimal Monetary Policy. Brookings Papers on Economic Activity, 2003(1), 139-211, https://doi. org/10.1353/eca.2003.0010

Fisher, A. G. B. (1935). Does an Increase in Volume of Production Call for a Corresponding Increase in Volume of Money. The American Economic Review, 25(2), 197-211.

Fisher, I. (1933). The Debt-Deflation Theory of Great Depressions. Econometrica, 1(4), 337-357, http://doi.org/10.2307/1907327

Galí, J. (2008). Monetary Policy, Inflation, and the Business Cycle: An Introduction to the New Keynesian Framework. New Jersey: Princeton University Press. ISBN 978-0-691-13316-4.

Garrison, R. W. (2001). Time and Money: The Macroeconomics of Capital Structure. London: Routledge. ISBN 978-0415771221.

Haberler, G. (1946) [1937]. Prosperity and Depression, 3rd Ed. New York: United Nations.

Hayek, F. A. von (1984) [1928]. Intertemporal Price Equilibrium and Movements in the Value of Money, in McCloughry, R., ed., Money, Capital, and Fluctuations: Early Essays. Chicago, IL: Chicago University Press, pp. 71-117, https://doi.org/10.7208/ chicago/9780226321271.001.0001 
(1933) [1929]. Monetary Theory and the Trade Cycle. London: Jonathan Cape.

(1935) [1931]. Prices and Production, 2nd Ed. New York: Augustus M. Kelly Publishers.

(1976). Denationalisation of Money. London: The Institute of Economic Affairs.

Jung, T., Teranishi, Y., Watanabe, T. (2005). Optimal Monetary Policy at the Zero-Interest-Rate Bound. Journal of Money, Credit and Banking, 37(5), 813-835, http://dx.doi.org/10.1353/ mcb.2005.0053

Komrska, M. (2015). Rakouská teorie hospodářského cyklu: VAR analýza pro USA v letech 1978-2013. Politická ekonomie, 63(1), 57-73, https://doi.org/10.18267/j.polek.988

Komrska, M., Hudík, M. (2016). Hayek's Monetary Theory and Policy: A Note on Alleged Inconsistency. The Review of Austrian Economics, 29(1), 85-92, https://doi.org/10.1007/ s11138-015-0300-5

Laubach, T., Williams, J. C. (2003). Measuring the Natural Rate of Interest. The Review of Economics and Statistics, 85(4), 1063-1070, https://doi. org/10.1162/003465303772815934

Mandel, M., Tomšík V. (2015). Dynamika a rovnováha úspor, investic a úvěru v hospodářském cyklu: příklad České republiky. (Dynamics and Balance of Savings, Investments, and Credits in Business Cycle - The Case of the Czech Republic.) Politická ekonomie, 63(1), 32-56, https://doi.org/10.18267/j.polek.987

Mankiw, N. G. (1985). Small Menu Costs and Large Business Cycles: A Macroeconomic Model of Monopoly. The Quarterly Journal of Economics, 100(2), 529-537, http://doi. org/10.2307/1885395

(2009). Macroeconomics, 7th Ed. New York: Worth Publishers.

Mankiw, N. G., Romer, D., eds. (1991). New Keynesian Economics. Cambridge, MT: MIT Press. ISBN 9780262132671.

McCallum, B. T. (2000). Theoretical Analysis Regarding a Zero Lower Bound on Nominal Interest Rates. Journal of Money, Credit and Banking, 32(4), 870-904, http://doi. org/10.2307/2601148

(2001). Monetary Policy Analysis in Models without Money. Review, Federal Reserve Bank of St. Louis, July, 145-164.

Mises, L. von (1976) [1912]. Theory of Money and Credit. New York: The Foundation for Economic Education.

Orphanides, A., Williams, J. C. (2002). Robust Monetary Policy Rules with Unknown Natural Rates. Brookings Papers on Economic Activity, 33(2), 63-146, https://doi.org/10.1353/ eca.2003.0007

Potužák, P. (2016a). Fisher and Mises on Zero Interest: A Reconsideration. Prague Economic Papers, 25(2), 202-220, https://doi.org/10.18267/j.pep.555

(2016b). Může být přirozená úroková míra nulová? Neoklasický přistup. (Can the Natural Rate of Interest Be Zero? A Neoclassical Approach.) Politická ekonomie, 64(1), 83-108, https://doi.org/10.18267/j.polek.1056

Robbins, L. (1934). The Great Depression. New York: Books for Libraries Press.

Romer, D. (2006). Advanced Macroeconomics, 3rd Edition. New York: McGraw-Hill.

Rothbard, M. N. (2004) [1962]. Man, Economy, and State. Auburn, AL: Ludwig von Mises Institute. (2000) [1963]. America's Great Depression. Ludwig von Mises Institute. 
Selgin, G. (1995). The "Productivity Norm" versus Zero Inflation in the History of Economic Thought. History of Political Economy, 27(4), 705-735, https://doi. org/10.1215/00182702-27-4-705

(1997). Less than Zero: The Case for a Falling Price Level in a Growing Economy. London: The Institute of Economic Affairs. ISBN 0255364024.

White, L. H. (1999). Hayek's Monetary Theory and Policy: A Critical Reconstruction. Journal of Money, Credit and Banking, 31(1), 109-120, https://doi.org/10.2307/2601142

Wicksell, K. (1936) [1898]. Interest and Prices. New Jersey: Augustus M. Kelley Publishers.

(1977) [1906]. Lectures on Political Economy, Volume 2. New Jersey: Augustus M. Kelley Publishers.

Williams, J. C. (2003). The Natural Rate of Interest. FRBSF Economic Letter, Federal Reserve Bank of San Francisco, Issue Oct 31.

Woodford, M. (2003). Interest and Prices: Foundations of a Theory of Monetary Policy. New Jersey: Princeton University Press. ISBN 978-0691010496.

(2008). How Important Is Money in the Conduct of Monetary Policy?

Journal of Money, Credit and Banking, 40(8), 1561-1598, https://doi.

org/10.1111/j.1538-4616.2008.00175.x 